\title{
A Rare Situation in Childhood: Anticholinergic Syndrome Due to Biperiden Intoxication
}

\author{
(1)Elif Çelik'
}

${ }^{1}$ Adnan Menders University Faculty of Medicine, Department of Pediatrics, General Pediatrics Unit, Aydın, Turkey

\begin{abstract}
Biperiden is an anticholinergic agent that acts on the central nervous system. It is used in the treatment of Parkinsonism and extrapyramidal symptoms. Anticholinergic syndrome develops in biperiden poisoning. Physostigmine is an effective central acetylcholinesterase inhibitor. In this article, we aimed to share our experience of using physostigmine in a case of central anticholinergic syndrome developing due to biperidene poisoning in a 4-year-old girl. Key words: Biperiden, physostigmine, child, intoxication.

\section{Özet}

Biperiden, merkezi sinir sistemine etki eden antikolinerjik bir ajandır. Parkinsonizm ve ekstrapiramidal semptomların tedavisinde kullanıı. Biperiden zehirlenmesinde antikolinerjik sendrom gelişir. Physostigmine etkili bir merkezi asetilkolinesteraz inhibitörüdür. Bu yazıda, 4 yaşındaki bir kız çocuğunda biperiden zehirlenmesine bağlı gelişen merkezi antikolinerjik sendrom vakasında fizostigmin kullanım deneyimimizi paylaşmayı amaçladık.

Anahtar kelimeler: Biperiden, fizostigmin, çocuk, zehirlenme
\end{abstract}

\section{Introduction}

Biperiden has been used in the management of the extrapyramidal syndromes that are observed in treatment protocol involving neuroleptics and antipsychotics. Its main effect is blockage of acetylcholine in the central nervous system ${ }^{1}$. Biperiden has fewer anticholinergic effects compared to atropine, although the anticholinergic properties of both are similar to each other. Thus, high-doses of biperidens, such as in intoxications, may lead to anticholinergic syndrome

Central nervous system symptoms include dilated pupils, depressive mood, hallucinations, and alterations in the mental state ranging from agitations to seizures. Mortality may increase in direct proportion to the dosage ${ }^{1}$. Even though the anticholinergic syndrome is commonly reported in adults, the syndrome is respectively rare in pediatric populations ${ }^{2-7}$.

Physostigmine, an inhibitor of the anticholinesterase enzyme, is used in the treatment of anticholinergic syndrome ${ }^{8,9}$.

In this case report, we aimed to present our experience on the treatment of anticholinergic syndrome as a result of biperiden intoxication using Physostigmine.

\section{Case Report}

A four-year-old female patient was admitted to our hospital from a secondary health-care center with a history of being found with an empty biperiden-containing medicine bottle (Akineton) and symptoms of flushing, fever, loss of balance, nonsense talking, and weird behaviors. In the initial examination, confused mental state, meaningless muttering, dryness in the skin and the oral mucosa, flushing on the cheeks, bilateral mydriatic pupils with absence of the pupillary reflex, diminished intestinal sounds, and distended bladder were noticed. Heart rate was 135 beats per minute, systolic and diastolic blood pressures were $125 \mathrm{mmHg}$ and $65 \mathrm{mmHg}$, respectively, respiration rate was 30 breath per minute, oxygen saturation was $92 \%$, and temperature was 38.3 degrees Celsius. Complete blood count and blood chemistry tests revealed normal results, and the patient was admitted to pediatric intensive care unit.

After nasogastric intubation and active choral administration via nasogastric route and intravenous hydration, physostigmine treatment was considered for anticholiner-

Corresponding Author: Elif Çelik e-mail: gencelif80@yahoo.com

Received: $11.03 .2020 \cdot$ Accepted: 25.09 .2020

Cite this article as: Celik E. A rare situation in childhood: anticholinergic syndrome due to biperiden intoxication. Eurasian J Tox. 2021;3(1):23-25. 
gic syndrome that was the result of biperiden intoxication. Physostigmine (Anticholium) was provided by local intoxication center after 8 hours and infused intravenously in 0.02 $\mathrm{mg} / \mathrm{kg}$ per dosage over 5 minutes. The dosage was repeated because the delirium state persisted even though the mucosal dryness improved apparently. A third repeat-dose was required because the mental state did not return to normal even after the appearance of pupillary reflex, loss of flushing as well as normalization of pulse rate. After the third dose, the mental state also improved and the patient was sedated. The follow-up period in the intensive care unit was observed without any other clinical problems. The patient was transferred to the ward after 24-hours of intensive unit follow-up, and was discharged with normal vital and mental findings in the third day of the admission.

\section{Discussion}

Central anticholinergic syndrome was initially described by Longo in 1966 as a group of symptoms that were associated with administration of anticholinergic drugs. However, etiology and pathophysiology of the syndrome could not be understood thoroughly ${ }^{10}$. Relative deficiency of acetylcholine in the synaptic ends is considered as the main culprit of the syndrome ${ }^{11}$. The syndrome may present by agitations, seizures, hallucinations, alterations in the mental state leading to coma, respiratory depression, and even to sudden death. In addition to neuromuscular agents, benzodiazepines, anesthetics such as ketamine, propofol, and nitrous oxide, as well as more than 500 therapeutic agents including atropine, scopolamine, and biperiden may trigger the syndrome $^{12}$. Biperiden has a central anticholinergic syndrome and acting akin to atropine. The competitive inhibition at the receptor level leads to anticholinergic syndrome ${ }^{13}$. Central effects are dose-dependent and include hallucinations, loss of short-term memory, agitations, respiratory failure, and cardiovascular collapse. Peripheral effects are mydriasis, dryness in the mucosa and skin, fever, tachycardia, ileus, and urinary retention.

In our case biperiden-related anticholinergic syndrome was primarily considered in the differential diagnosis because of observation of the basic features of the syndrome, such as dryness in all mucosal surfaces and skin, flushing, mydriasis, and mental state alteration in a previously-healthy child who was found with a biperiden-containing drug container. Delirium state, which was also observed in our case, is the most common mental state alteration in the anticholinergic syndrome ${ }^{14}$.

The diagnosis of the central anticholinergic syndrome depends on the clinical suspicion and relief of the syndrome after physostigmine administration, which further confirms the diagnosis ${ }^{15}$. Physostigmine, which enhances the activity of acetylcholine by inhibiting the acetylcholine esterase enzyme, is the first choice in the treatment of the syndrome because of its high permeability to the central nervous system $^{16}$.

Physostigmine has a relatively fast effect that sustains up to 60 minutes ${ }^{17}$. The dosage is $0.02 \mathrm{mg}$ per $\mathrm{kg}$ for children and the maximum administration speed is $0.5 \mathrm{mg}$ per minute. Thus, the total dose can be administered via intravenous route in minutes. If the desired effects are not observed, a repeat-dose can be administered with ten to thirty minutes of intervals. The maximum dosage is $2 \mathrm{mgs}$. The side effects, bradycardia, intense sweating and lacrimation, nausea, and hyperperistalsis are related to anticholinergic activity of physostigmine $^{18}$.

Delivery of physostigmine to health-care centers in our country is limited. Thus, the contemporary literature has respectively low number of reports in the usage of physostigmine. Some authors underlined the severe side effects of physostigmine such as cholinergic crisis or asystole, and reported the benzodiazepines as their first-choice in the treatment of the anticholinergic syndrome ${ }^{19}$. In a contemporary review, retrospective data of 815 patients who were treated with the diagnosis of the anticholinergic syndrome was reviewed and it was concluded that physostigmine is safer than benzodiazepines and other sedatives with less intubation risk $^{20}$.

In our patient, we observed complete relief after the third dose of physostigmine without any significant side effects.

\section{Conclusion}

It should be remembered that physostigmine can be used in the treatment of serious clinical conditions that may occur in pediatric patients presenting with drugs intoxication that may cause anticholinergic syndrome such as biperiden.

\section{References}

1. Dose $M$, Tempel H. Abuse potential of anticholinergics. Pharmacopsychiatry, 2000; 33(Sup. 1):43-6.

2. Hammon K, DeMartino BK. Postoperative delirium secondary to atropine premedication. Anesth Prog, 1985;32:107-8.

3. Holzgrafe RE, Vondrell JJ, Mintz SM. Reversal of postoperative reactions to scopolamine with physostigmine. Anesth Analg, 1973; 52:921-5

4. Kaiser Stadler M, Altmayer P. Central anticholinergic syndrome after propofol anesthesia. Anasthesiol Intensivmed Notfallmed Schmerzther, 1995; 30:116-7.

5. Schultz U, Idelberger R, Rossaint R, Buhre W. Central anticholinergic syndrome in a child undergoing circumcision. Acta Anaesthesiol Scand, 2002; 46:224-6.

6. Hagemann HD, Prass D, Hausdorfer J. A case of central anticholinergic syndrome in pediatric anesthesia.Anaesthesist, 1988; 37:193-5 
7. Holland MS. Central anticholinergic syndrome in a pediatric patient following transdermal scopolamine patch placement. Nurse Anesth, 1992;3:121-4.

8. Grace RF. Benztropine abuse and overdose case report and review. Adverse Drug React Toxicol Rev. 1997;16: 103-12.

9. Katsanoulas K, Papaioannou A, Fraidakis O, Michaloudis D. Undiagnosed central anticholinergic syndrome may lead to dangerous complications. Eur J Anaesthesiol, 2000; 17: 466-7.

10. Longo VG. Behavioral and electroencephalographic effects of atropine and related compounds. Pharmacol Rev, 1966;18:965-96.

11. Kulka PJ, Toker H, Heim J, Joist A, Jakschik J. Suspected Central Anticholinergic Syndrome in a 6-Week-Old Infant. Anesth Analg, 2004; 99:1376 -8.

12. Schneck HJ, Rupreht J. Central anticholinergic syndrome (CAS) in anesthesia and intensive care. Acta Anaesthesiol Belg, 1989:49: 219-28.

13. Hewer W, Biedert S. Delirium syndrome in biperiden poisoning. Fortschr Neurol Psychiatr, 1988;56: 133-6.

14. Köse R, Şahin ÖÖ, Abay E. Datura stramonium zehirlenmes- ine bağlı deliryum: Bir olgu. Anatolian Journal of Psychiatry, 2008;9: 54-7.

15. Duvoisin RC, Katz R. Reversal of central anticholinergic syndrome in man by physostigmine. JAMA, 1968:25: 1963-5.

16. Buchanan JF. Physostigmine as an antidote. Clin Toxicol Update, 1986;8:13-16.

17. Hartvig $P$, Wiklund $L$, Lindström B. Pharmacokinetics of physostigmine after intravenous, intramuscular and subcutaneous administration in surgical patients.Acta Anaesthesiol Scand, 1986:30: 177-82.

18. Lauven PM, Calaminus JM. Antagonists in anesthesia. Anaesthesiol Intensivmed Notfallmed Schmerzther, 1995:30: $331-6$.

19. Watkins JW, Schwarz ES, Arroyo-Plasencia AM, Mullins ME; Toxicology Investigators Consortium investigators. The Use of Physostigmine by Toxicologists in Anticholinergic Toxicity. J Med Toxicol, 2015;11: 179-84.

20. Espi Martinez F, Espi Forcen F, Shapov A, Martinez Moya A. Biperiden dependence: case report and literature review. Case Rep Psychiatry, 2012;2012: 949256. 